\title{
Articles
}

\section{REGIONAL CONVERGENCE OF LABOUR PRODUCTIVITY IN RURAL SECTORS IN THE CONTEXT OF FUNDS OBTAINED FOR AGRICULTURE FROM THE EUROPEAN UNION}

\author{
MIECZYSEAW ADAMOWICZ \\ ADAM SZEPELUK
}

\begin{abstract}
One of the key goals of European integration is the reduction of development disparities referred to as convergence. Convergence occurs in two forms as sigma convergence and beta convergence. Sigma convergence means a decrease in dispersion and differentiation over time, and the essence of beta convergence is faster development of less developed regions or countries, which results in catching up. The aim of the article is to study the convergence of the level of development of the sectors of the rural economy in the regions of Poland between 2003and 2014. The economic results, in the context of the size of funds raised from European funds, measured by the gross value added of agriculture, forestry, hunting and fisheries, were obtained from the Local Data Bank. Data on the value of the funds used were obtained from the Agency for Restructuring and Modernization of Agriculture. Statistical methods describing the state of differentiation of regions and the function of regression were used for the analysis. The research confirmed partial occurrence of labour productivity convergence in the rural sectors of the Polish regions and a positive correlation of gross value added with the amount of obtained funds from European funds.
\end{abstract}

Keywords: convergence, regions, rural development.

JEL codes: Q18, R51, R58.

\footnotetext{
Prof. dr hab. Mieczysław Adamowicz, Państwowa Szkoła Wyższa w Białej Podlaskiej, Katedra Ekonomii i Zarządzania; ul. Sidorska 95/97, 21-500 Biała Podlaska (adamowicz.mieczyslaw@gmail.com) ORCID 0000-0002-1164-4966.

Mgr Adam Szepeluk, Państwowa Szkoła Wyższa w Białej Podlaskiej, Centrum Badań Nad Innowacjami; ul. Sidorska 105, 21-500 Biała Podlaska (a.szepeluk@pswbp.pl) ORCID 0000-0003-0406-3423.
} 


\section{Introduction}

One of the main goals of the European integration is to reduce disparities in development between Member States and regions on their territory. At the initial stages of development of the integration, the differences between countries were small, because five founding countries, coming from the same cultural and civilisation circle, were characterised by territorial cohesion and a similar level of economic development. These differences were increasing along with the successive enlargements of the Community, first with Denmark, Ireland and the United Kingdom (1973), then with Greece (1981), Spain and Portugal (1986), followed by the GDR (1990), Austria, Sweden, and Finland (1995), to reach large sizes after the fifth enlargement of the Union with the countries of Central and Southern Europe. Admission of Ireland, Greece, Spain and Portugal to the Community resulted in the introduction of a cohesion policy and a new fund for strengthening territorial, transport, economic and social cohesion. The current process of enlargement of the European Union with the Balkan countries raises the issue of significance of socio-economic differences in Member States and their regions, creates a greater demand for resources and complicates ways of approach to solving problems resulting therefrom. Therefore, it can be concluded that as the European Union expands to new countries, the magnitude of problems of regional differentiation is growing and the number of less developed regions requiring assistance is increasing. An important feature of these regions is that they are agricultural regions and often have a peripheral location.

Equalising disparities in development at the level of the countries and regions of the European Union is called convergence, which in a general sense expresses the process of "bringing closer" and "reducing differences" between countries and regions; and the phenomenon of catching up with more developed areas by weaker ones. Convergence is one of the objectives of the European integration, and designed development strategies and policies.

The problem of regional variation and increasing the efficiency of resources directed to development of less developed regions was noticed in the mid-1980s, when actions were taken to strengthen structural policy instruments, reforming the use of the regional fund and structural funds and introducing structural elements to the Common Agricultural Policy. Strengthening the regional aspect of the Common Agricultural Policy initiated by the McSharry reform of 1992 was related to the new reform of agricultural funds carried out at that time and the strengthening of the second pillar of the Common Agricultural Policy, directed at the rural development programme.

The objective of the article is to assess the impact of financial support for Polish agriculture and other sectors of rural economy in political and administrative regions (voivodeships) in Poland. This objective was achieved by assessing the convergence of regions measured by the level and dynamics of increase in gross value added in the sectors of section A (agriculture, forestry, hunting and fishing) per person employed in these sectors, and per value of co-financing from the RDP in 2005-2014. 


\section{Convergence as the objective of the European integration}

Convergence is a process in which various initially dissimilar phenomena become similar, which means the disappearance of inequalities between entities, between countries or regions. The opposite of convergence is divergence, which means the deepening of differences. On economic grounds, the concept of convergence was formulated for the first time in the 1940s by Jan Tinbergen, although Schumpeter and Kondratiev (Churski, 2005) can also be regarded as the precursors of this phenomenon. The processes of socio-economic development are characterised by uneven course in time and space, which is expressed by occurrence of convergence cycles (time system) and formation of disparities in development (spatial system). The phenomenon of convergence is related to the inequality of economic development in spatial systems measured by GDP per capita.

Other measures adapted to the characteristics of the studied phenomenon may also be used to determine the level of achieved development in the spatial system. Nowadays, it is acknowledged, although there are considerable differences of opinion in this respect, that excessive differences in development in spatial systems are not favourable, which is the basis for opposing these processes, as well as for pursuing policies to eliminate territorial developmental differences. This assumption is the basis for European integration. The Preamble of the Treaty of Rome of 1957, establishing the EEC, stipulates that the purpose of functioning of the Community is harmonious development by reducing the differences existing between the various regions and the backwardness of the less favoured regions. This provision has been reproduced in successive treaties as one of the most important measures within the framework of Community policies, especially the structural policy, regional policy or cohesion policy. As the integration expanded and deepened, these provisions were supplemented. The definition of the principles of cohesion policy was of key importance in this respect, which involved the establishment of the Single European Act (SEA) in 1986 and joining the Community by relatively poorer countries like Greece, and later Spain and Portugal. The SEA introduced new treaty provisions strengthening economic and social cohesion and the new Cohesion Fund, and the Treaty of Lisbon a new category of territorial cohesion and social cohesion. The structural policy reform carried out in the mid-1980s brought a number of new rules, including the principle of multi-annual programming of expenditure for development purposes and their allocation to problem areas. Therefore, the phenomena and processes of convergence were recognised as the official objective of structural policy, which also influenced the shape of other Community policies, including the Common Agricultural Policy. During the 1989-1993 programming period, the EU's structural policy objectives included provisions regarding support and structural adjustment of economically backward regions, restructuring of economic sectors in border regions and regions affected by industrial decline, and adjustment of agrarian structures and support for rural areas as part of reforms of the Common Agricultural Policy implemented since 1992. 
In the 1994-1999 programming period, apart from development priorities aimed at strengthening development of the regions affected by difficulties in industrial development, there were new provisions on the advisability of supporting agricultural areas, facilitating development and structural transformation of rural areas, and promotion of development and structural adjustments in regions with low population density. Between 2000 and 2006, when the fifth enlargement of the European Union with the Central and Eastern European and Southern European countries took place, three priorities were adopted, two of which were regional, i.e. promoting development and structural adjustment of regions whose development is lagging behind and supporting economic and social convergence of areas facing structural problems.

In the 2007-2013 programming period, all three priorities of the structural policy included spatial aspects, but formally the objective referred to as convergence was identified and recognised as a priority. In principle, regional competitiveness and employment, as well as European territorial cooperation also served to accelerate development and eliminate regional differences, and thus to create and strengthen the phenomenon of convergence. In 2000-2006, over $70 \%$ of structural funds were allocated to convergence, and in the next financial perspective this percentage increased to $80 \%$ (Głodowska, 2012). The convergent-oriented objective covered the regions at NUTS 2 level where the gross domestic product per capita, calculated on the basis of data for 2000-2002, was no more than 75\% of the average GDP for the EU-25. In 2001-2003, this threshold was raised to $90 \%$.

The focus of the cohesion policy for 2014-2020 shifted from a regionally oriented way of acting to a more problem-oriented one. Depending on the level of GDP, regions are divided into categories of more developed regions, transition regions or less developed regions. The coverage of costs of projects from structural funds from $50 \%$ to $80 \%$ developed on the basis of this division. The next policy objective was to increase the competitiveness of European regions and cities, and to stimulate economic growth and employment. Out of the planned total amount of EUR 351.8 billion of cohesion policy support, in 2014-2020, almost 52\% was allocated for less developed regions pursuing the convergence objective, about $15 \%$ for more developed regions, mainly pursuing the competitiveness objective, about $10 \%$ for transition regions, and the rest, i.e. around $23 \%$, for the outermost and sparsely populated regions and for technical assistance.

The question arises of how agriculture, which is strongly dependent on natural conditions, has a spatial nature and is characterised by lower profitability than other economic sectors, is incorporated into the implementation of the convergence concept. It seems that in the context of convergence of agriculture there are two types of impact. The first one consists in strong support for agriculture as a sector inefficient in terms of income and characterised by low labour productivity through the Common Agricultural Policy. In this case, support for agriculture means support for development of agricultural regions, therefore less developed regions. This is particularly visible by supporting agriculture in areas with natural handicaps. Without funds directed to agriculture, the effects of managing these areas would be weaker. The second type of support of agricultural convergence is related to sup- 
port for development of rural areas, i.e. for new forms of non-agricultural activities and multipurpose farming. Support for agriculture, both through internal market instruments and support for foreign trade, was introduced in the sixties and maintained during various reforms of the Common Agricultural Policy until today. From the beginning, sectoral support for agriculture has been maintained (under the first pillar of the Common Agricultural Policy), and over time it has been introduced and strengthened by the impact of structural changes in agriculture and enriching non-agricultural sectors of rural economy through the introduction of the second pillar of the CAP supporting rural development.

Structural policy towards agriculture, initiated in the 1970s, was strengthened during the MacSharry reforms of 1992. This strengthening was continued as a result of the reform introduced by Agenda 2000, the Luxembourg reform of 2003, the so-called Health Check of 2007, or the contemporary concept of the Common Agricultural Policy. The implementation of the Rural Development programme in 2000-2006 and 2007-2013 made the model of impact on rural areas by the Common Agricultural Policy similar to actions under the cohesion policy, which from the very beginning was clearly directed at the convergence of countries and regions.

Considering the general transformation of the objectives, solutions and instruments of the Common Agricultural Policy and transfers for agriculture resulting from this policy, it should be noted that the amount of support for agriculture and rural areas in countries and regions proceeds in accordance with the convergence processes. The question arises as to whether there is convergence of the amount of support in agricultural policy in selected countries (Czyżewski and Kułyk, 2009) and whether the streams of support flowing through the Common Agricultural Policy contribute to the convergence processes of the level of development of agriculture itself in the countries and regions of the European Union. While leaning to the legitimacy of confirming such an impact, it should be noted that opinions doubting that the implementation of the Common Agricultural Policy is a factor in the convergence of agriculture and strengthening the concept of sustainable development of agriculture on a regional scale are not isolated (Smędzik-Ambroży, 2014). Research done in this paper is aimed at addressing the existence and scale of convergence of agriculture in Poland.

Similarly to support for regions through cohesion policy, in the case of spatial distribution of support through agricultural policy measures, there is a dilemma of choice between the method ensuring greater competitiveness and efficiency and the objective of increasing convergence, less effectively but mitigating differences in development regionally. The convergence policy on the European Union scale, resulting in the equalisation of the GDP per capita in the regions, did not bring about the strengthening of the Union's competitiveness on an international scale (Głodowska, 2012). Due to the economic crisis of the first decade of the $21^{\text {st }}$ century and the failure of the Lisbon Strategy, the assumptions of the Europe 2020 strategy paid more attention to the need to increase competitiveness. The priorities for 2014-2020, of both structural policy and agriculture and rural development policy, should therefore provide for a balance between ensuring competitiveness and regional convergence of agriculture. 


\section{Research method}

There is a significant diversification of the production potential and economic results of agriculture in a regional arrangement in Poland (Kaczmarek, 2006; Kamińska and Nowak, 2014). The phenomena of regional convergence of agriculture were investigated by many authors, such as Czyżewski and Kułyk (2009), Brelik and Grzelak (2011), Niewiadomski (2009), Rezitis (2010), Sapa and Baer-Nawrocka (2014), Majchrzak and Smędzik-Ambroży (2014), Nowak (2017), Bráth and Ferto (2017) and others. It can be assumed that the level of achieved production results was significantly affected by the size of the EU funds directed to agriculture and rural areas both under the Common Agricultural Policy and cohesion policy. The question arises whether the inflow of such funds becomes a source of regional convergence of productivity of agriculture and other natural sectors on rural areas.

In the attempt to assess the convergence of agriculture in Polish voivodeships in 2003-2014 in the light of the use of funds for supporting development of agriculture and rural areas, it was necessary to settle methodical issues concerning three areas:

- the area of measuring the level of agricultural development,

- the area of the level of resources from European funds used,

- the area of adopted definitions of convergence measurement methods.

The level of agricultural development is usually measured by comparing production results per unit of labour, per hectare of land used or by comparison to the factor of capital used. While examining the phenomenon of convergence, different categories defining the results of farming per head, per hectare or other factor of production can also be used (Sapa and Baer-Nawrocka, 2014). In the presented paper, the effects of farming and the level of rural development in voivodeships were determined by the gross value added per person employed (GVA/PE) in section A, which includes agriculture, forestry, hunting and fishing. The adoption of this measure is justified by the role of the labour factor in production processes in rural sectors. This measure does not take into account the value generated in other sectors, especially in the sector of services provided in rural areas. We assume that this simplification will not distort the picture of convergence in rural areas. In addition, one should bear in mind that the occurrence of the phenomenon of convergence and its level cannot be equated only with the adopted measurement indicators, because it is a complex phenomenon, dependent on many other socio-economic, technical and business conditions (Łaźniewska, Górecki and Chmielewski, 2011).

The level of funds for development of agriculture and rural areas includes the size of transfers under the first and the second pillar of the Common Agricultural Policy, including mainly the amount of direct payments for agriculture and subsidies implemented in the rural development programme.

Two basic definitions of regional convergence were adopted for its studies: sigma-convergence and beta-convergence. An attempt was also made to determine the cor- 
relation between the convergence of the effects of farming in rural areas and the level of inflow of the EU funds to these areas.

Sigma $(\sigma)$ convergence defines the dispersion of the studied phenomenon over time. The variance and standard deviation were assumed as the measure of dispersion. The occurrence of the phenomenon of convergence is demonstrated by the reduction of differences, i.e. the analysed variables become assimilated. In the case of increasing differences, the phenomenon of divergence will occur.

$\operatorname{Beta}(\beta)$ convergence characterises the relation between the pace of change in the level of development of sectors in section A and informs how much its initial values change, while respecting the principles that convergence takes place when the growth rate in units with a lower initial level is higher than the average. As a result, the phenomenon of catching up with more developed regions by the weaker ones occurs. The occurrence of beta-convergence is considered essential for sigma-convergence (Wójcik, 2008, p. 42).

Club convergence or conditional convergence occurs when only regions with similar initial characteristics approach each other. According to this concept, the convergence of development levels takes place in groups, despite the polarisation of the whole population remaining at an unchanged level.

The formula for the standard deviation of the logarithm of the gross value added per person employed in agriculture was used to verify $\sigma$-convergence (Fiedor and Kociszewski, 2010; Nowak, 2007).

$$
\delta(t)=\sqrt{\frac{1}{n} \sum_{i=1}^{n}\left(\log y_{i}(t)-\bar{y}(t)\right)^{2}} \quad \text { gdzie: }
$$

where:

gdzie:

$$
\bar{y}(t)=\frac{1}{n} \sum_{i=1}^{n} \log y_{i}(t)
$$

$\delta(t)$ - dispersion of the GVA per person employed in agriculture in the group of all regions in year $t$,

$y_{i}(t)$ - the GVA per person employed in agriculture in $i$-th region in period $t$, $\bar{y}(t)$ - the average GVA per person employed in agriculture in period $t$.

The decrease in the value of the $\delta$-convergence rate in the analysed period indicates a decrease in the disproportion in the level of the analysed feature. In the opposite situation, sigma-divergence will occur (Barro and Sala-i-Martin, 1992; Malaga, 2004).

The regression of the GVA increase per person employed during the period under study in relation to the constant of the initial level of the formula was used to determine absolute beta-convergence (Próchniak and Rapacki, 2007). 


$$
\frac{1}{t}\left(\ln y(t)-\ln y(0)=\alpha_{0}+\alpha_{1} m y(0)+\varepsilon\right.
$$

where:

$y(t)$ - the GVA in the final year,

$y(0)$ - the GVA in the initial year,

$t+1$ - number of periods,

$\varepsilon \quad$ - random element.

$\beta$-convergence occurs when $a_{1}$ parameter is negative, while the closer the value is to -1 , the greater the convergence. The classic analysis of convergence can be modified and enriched, e.g. through the application of alternative methods using a full distribution of the analysed feature and its changes over time (Wójcik 2008). The results obtained from the calculations and estimations carried out can be presented both in pictorial, numerical and graphic terms.

\section{Convergence of gross value added per person employed}

The productivity of agriculture and other natural sectors in rural areas, measured by the gross value added (GVA) per person employed (PE) in section A (agriculture, forestry, hunting, fishing) is strongly differentiated regionally (Table 1). At the beginning of the studied period, the difference in the GVA/PE between the Podkarpackie region, which had the lowest ratio of PLN 2.8 thousand/person in 2003, and the Zachodniopomorskie region, where it amounted to PLN 24.0 thousand/person, was PLN 21.2 thousand. So it was an 8.6-fold difference. In 2014, these differences deepened, in the Podkarpackie region labour productivity increased to only 3.8 thousand GVD/PE and in Zachodniopomorskie to 39.7 thousand GVA/PE, which means to the level tenfold higher than in the Podkarpackie region. Two above-mentioned regions of Poland represent extremely different types of agriculture and extremely different natural conditions of functioning of rural economy. While on average between 2003 and 2014, the productivity ratio in Poland amounted to PLN 18.7 thousand, in four regions (Podkarpackie, Małopolskie, Lubelskie, Świętokrzyskie) it was below 10 thousand/person, and in two (Zachodniopomorskie and Lubuskie) it exceeded 30 thousand/person (Table 1). These two groups of regions are characterised by large differences in population density, different agricultural structures, different natural conditions and different nature of rural areas. 
Table 1

Gross value added per person employed in PLN thousand/person in 2003-2014

\begin{tabular}{|c|c|c|c|c|c|c|c|c|c|c|c|c|c|}
\hline \multirow{2}{*}{ Voivodeship } & \multicolumn{13}{|c|}{ Year } \\
\hline & 2003 & 2004 & 2005 & 2006 & 2007 & 2008 & 2009 & 2010 & 2011 & 2012 & 2013 & 2014 & Average \\
\hline Dolnośląskie & 15.6 & 19.2 & 18.2 & 16.9 & 22.2 & 18.1 & 19.5 & 18.3 & 22.7 & 21.4 & 21.3 & 20.4 & 19.5 \\
\hline $\begin{array}{l}\text { Kujawsko- } \\
\text {-Pomorskie }\end{array}$ & 12.3 & 20.6 & 17.2 & 16.4 & 19.2 & 17.6 & 19.3 & 22.6 & 25.9 & 26.4 & 30.7 & 28.1 & 21.4 \\
\hline Lubelskie & 5.2 & 6.5 & 5.9 & 5.7 & 8.8 & 8.0 & 8.0 & 8.7 & 11.5 & 10.6 & 11.6 & 10.2 & 8.4 \\
\hline Lubuskie & 18.2 & 32.7 & 28.8 & 24.9 & 33.6 & 27.6 & 33.0 & 27.9 & 34.7 & 33.7 & 35.8 & 36.0 & 30.6 \\
\hline Łódzkie & 8.9 & 12.8 & 11.9 & 12.8 & 16.8 & 15.6 & 14.5 & 15.9 & 18.9 & 17.6 & 19.2 & 20.1 & 15.4 \\
\hline Małopolskie & 5.1 & 6.7 & 7.1 & 7.3 & 10.3 & 9.5 & 8.5 & 5.5 & 6.8 & 6.2 & 6.1 & 6.2 & 7.1 \\
\hline Mazowieckie & 11.6 & 15.5 & 15.6 & 17.0 & 20.7 & 20.9 & 20.1 & 24.5 & 29.7 & 28.6 & 33.1 & 29.7 & 22.3 \\
\hline Opolskie & 11.9 & 17.0 & 16.3 & 16.0 & 20.1 & 17.4 & 16.9 & 20.8 & 25.3 & 24.1 & 22.8 & 21.0 & 19.1 \\
\hline Podkarpackie & 2.8 & 4.1 & 4.6 & 4.4 & 6.9 & 6.3 & 5.7 & 3.3 & 4.2 & 3.8 & 4.2 & 3.8 & 4.5 \\
\hline Podlaskie & 6.9 & 11.4 & 11.9 & 12.1 & 14.1 & 13.1 & 15.3 & 17.6 & 20.2 & 19.4 & 23.0 & 20.1 & 15.4 \\
\hline Pomorskie & 14.5 & 19.1 & 16.8 & 16.9 & 23.0 & 19.6 & 23.1 & 25.3 & 29.1 & 30.5 & 31.8 & 32.2 & 23.5 \\
\hline Śląskie & 13.3 & 15.9 & 16.4 & 13.5 & 18.1 & 17.5 & 18.3 & 12.1 & 14.7 & 14.9 & 14.7 & 13.8 & 15.3 \\
\hline Świętokrzyskie & 6.7 & 8.1 & 6.7 & 7.1 & 9.6 & 8.8 & 8.8 & 8.6 & 10.7 & 9.6 & 10.5 & 10.1 & 8.8 \\
\hline $\begin{array}{l}\text { Warmińsko- } \\
\text {-Mazurskie }\end{array}$ & 19.1 & 24.5 & 24.0 & 24.0 & 26.4 & 23.2 & 27.8 & 32.1 & 38.5 & 37.0 & 37.8 & 36.5 & 29.2 \\
\hline Wielkopolskie & 16.2 & 24.6 & 22.9 & 21.5 & 23.4 & 19.7 & 22.7 & 24.0 & 26.6 & 28.1 & 29.5 & 28.2 & 24.0 \\
\hline $\begin{array}{l}\text { Zachodnio- } \\
\text { pomorskie }\end{array}$ & 24.0 & 34.2 & 29.8 & 31.3 & 32.8 & 28.8 & 36.0 & 34.6 & 37.1 & 38.7 & 42.5 & 39.7 & 34.1 \\
\hline Poland & 12.0 & 17.1 & 15.9 & 15.5 & 19.1 & 17.0 & 18.6 & 18.9 & 22.3 & 21.9 & 23.4 & 22.3 & 18.7 \\
\hline
\end{tabular}

Source: own study based on the Local Data Bank.

In order to calculate the size of the convergence phenomenon, it is necessary to convert absolute values into relative values in individual voivodeships and compare them to the GVA/PE at the level of the whole country. This procedure allows comparing data for particular years without using the value-added deflator.

In 2003, the relative gross value added per person employed in agriculture (GVA/ PE) reached the highest value in the case of Zachodniopomorskie Voivodeship (240.2\%), Warmińsko-Mazurskie Voivodeship (191.1\%) and Lubuskie Voivodeship (181.9\%). The lowest value of the GVA/PE in 2003 was recorded by the Podkarpackie (27.7\%), Małopolskie (50.9\%) and Lubelskie Voivodeships (52.2\%). The Łódzkie, Podlaskie and Świętokrzyskie Voivodeships were also below the national average. In 2014, the highest value of relative GVA/PE was achieved by the same voivodeships as in 2003, i.e.: Zachodniopomorskie Voivodeship (216.6\%), Warmińsko-Mazurskie Voivodeship (199.2\%) and Lubuskie Voivodeship (196.3\%). The lowest value of GVA/PE in 2014 was recorded by the Podkarpackie (20.8\%), Małopolskie (33.6\%), Świętokrzyskie $(55.1 \%)$ and Lubelskie Voivodeships $(55.9 \%)$. The rate was also lower than the national average in the Śląskie Voivodeship. The Łódzkie and Podlaskie Voivodeships raised their rates to the level above the national average (Table 2). 
Table 2

Dynamics of distribution of the gross value added per one person working in relation to the

\begin{tabular}{|c|c|c|c|c|c|c|c|c|c|c|c|c|}
\hline \multirow{2}{*}{ Voivodeship } & \multicolumn{12}{|c|}{ Year } \\
\hline & 2003 & 2004 & 2005 & 2006 & 2007 & 2008 & 2009 & 2010 & 2011 & 2012 & 2013 & 2014 \\
\hline Dolnośląskie & 155.7 & 137.2 & 137.0 & 127.6 & 134.7 & 120.2 & 124.1 & 118.2 & 123.7 & 119.5 & 109.4 & 111.1 \\
\hline $\begin{array}{l}\text { Kujawsko- } \\
\text {-Pomorskie }\end{array}$ & 123.1 & 147.0 & 129.7 & 123.9 & 116.5 & 117.1 & 123.1 & 146.2 & 140.9 & 147.1 & 157.4 & 153.5 \\
\hline Lubelskie & 52.2 & 46.7 & 44.4 & 43.3 & 53.4 & 52.9 & 50.6 & 56.4 & 62.4 & 59.3 & 59.7 & 55.9 \\
\hline Lubuskie & 181.9 & 233.3 & 216.8 & 188.0 & 204.4 & 183.4 & 210.0 & 180.7 & 188.5 & 188.1 & 183.4 & 196.3 \\
\hline Łódzkie & 88.7 & 91.0 & 89.3 & 96.8 & 102.2 & 103.7 & 92.3 & 103.1 & 102.7 & 98.2 & 98.6 & 109.5 \\
\hline Małopolskie & 50.9 & 47.6 & 53.6 & 55.1 & 62.3 & 63.1 & 54.3 & 35.9 & 36.9 & 34.8 & 31.3 & 33.6 \\
\hline Mazowieckie & 116.2 & 110.7 & 117.4 & 128.1 & 125.6 & 139.1 & 127.9 & 158.7 & 161.5 & 159.4 & 169.8 & 161.8 \\
\hline Opolskie & 118.8 & 121.2 & 122.9 & 120.8 & 122.2 & 115.8 & 107.8 & 134.8 & 137.7 & 134.4 & 116.8 & 114.6 \\
\hline Podkarpackie & 27.7 & 29.2 & 34.6 & 33.4 & 41.9 & 41.9 & 36.4 & 21.2 & 22.7 & 21.1 & 21.6 & 20.8 \\
\hline Podlaskie & 69.0 & 81.0 & 89.7 & 91.4 & 85.6 & 87.2 & 97.7 & 113.7 & 109.9 & 108.0 & 117.9 & 109.4 \\
\hline Pomorskie & 145.6 & 136.1 & 126.5 & 127.6 & 139.8 & 130.0 & 147.0 & 163.5 & 158.0 & 169.9 & 162.8 & 175.8 \\
\hline Śląskie & 133.1 & 113.2 & 123.3 & 101.6 & 110.2 & 116.1 & 116.3 & 78.6 & 79.8 & 83.3 & 75.2 & 75.2 \\
\hline Świętokrzyskie & 66.7 & 58.1 & 50.8 & 53.6 & 58.1 & 58.7 & 55.7 & 55.3 & 58.1 & 53.6 & 53.7 & 55.1 \\
\hline $\begin{array}{l}\text { Warmińsko- } \\
\text {-Mazurskie }\end{array}$ & 191.1 & 174.5 & 180.5 & 181.1 & 160.6 & 154.2 & 177.1 & 207.9 & 209.4 & 206.4 & 193.8 & 199.2 \\
\hline Wielkopolskie & 162.1 & 175.2 & 172.4 & 162.0 & 142.1 & 131.1 & 144.7 & 155.3 & 144.8 & 156.5 & 151.5 & 154.0 \\
\hline $\begin{array}{l}\text { Zachodnio- } \\
\text { pomorskie }\end{array}$ & 240.2 & 243.7 & 224.7 & 236.1 & 199.1 & 191.1 & 229.2 & 223.9 & 201.5 & 215.5 & 217.7 & 216.6 \\
\hline
\end{tabular}

Source: as for Table 1.

Taking into account the initial and final year, the number of voivodeships with productivity lower than the average increased from 6 to 7 .

A comparison of individual years from the initial and final period may include a significant number of random elements; a more objective picture may be obtained by using averages from several years. When we use the three-year average, there were 7 voivodeships below the average in the initial period, whereas in the final period the number of voivodeships decreased to 6 . The average gross value added per person employed in relation to the country in 2003-2005 was: $120.5 \pm 59.7$ and increased in 2012-2014 to the level of 121.2 \pm 60.4 . The largest increase was recorded in the Mazowieckie Voivodeship (48.9 points), Pomorskie Voivodeship (33.4) and Podlaskie Voivodeship (31.9), and the largest decrease in: Śląskie (-4.3), Dolnośląskie (-30.0) and Lubuskie Voivodeships (-21.4). The average increase was 0.7 , i.e. $0.6 \%$ (Table 3 ). 
Table 3

Dynamics of distribution of the gross value added per one person working in relation to the country ${ }^{a}$

\begin{tabular}{lrrcc}
\hline \multicolumn{1}{c}{ Voivodeship } & $2003-2005$ & $2012-2014$ & $\begin{array}{c}\text { Change } \\
\text { (percentage points) }\end{array}$ & $\begin{array}{c}\text { Change } \\
(\%)\end{array}$ \\
\hline Dolnośląskie & 143.3 & 113.3 & -30.0 & -20.9 \\
Kujawsko-Pomorskie & 133.3 & 152.7 & 19.4 & 14.6 \\
Lubelskie & 47.8 & 58.3 & 10.5 & 22.1 \\
Lubuskie & 210.7 & 189.3 & -21.4 & -10.2 \\
Łódzkie & 89.7 & 102.1 & 12.4 & 13.9 \\
Małopolskie & 50.7 & 33.2 & -17.5 & -34.5 \\
Mazowieckie & 114.8 & 163.7 & 48.9 & 42.6 \\
Opolskie & 121.0 & 121.9 & 1.0 & 0.8 \\
Podkarpackie & 30.5 & 21.2 & -9.3 & -30.6 \\
Podlaskie & 79.9 & 111.8 & 31.9 & 39.9 \\
Pomorskie & 136.1 & 169.5 & 33.4 & 24.6 \\
Śląskie & 123.2 & 77.9 & -45.3 & -36.8 \\
Świętokrzyskie & 58.5 & 54.1 & -4.4 & -7.5 \\
Warmińsko-Mazurskie & 182.0 & 199.8 & 17.8 & 9.8 \\
Wielkopolskie & 169.9 & 154 & -15.9 & -9.4 \\
Zachodniopomorskie & 236.2 & 216.6 & -19.6 & -8.3 \\
- Average & 120.5 & 121.2 & 0.7 & 0.6 \\
Standard deviation & 59.7 & 60.4 & 25.7 & -3.4 \\
Median & 122.1 & 117.6 & -1.7 & \\
\hline
\end{tabular}

a Three-year averages from the initial and final period of analysis (\%).

Source: as for Table 1.

The median of change was $-3.4 \%$, which indicates that half of the studied voivodeships recorded a drop in the analysed indicator by $3.4 \mathrm{pp}$, from $122.1 \%$ to $117.6 \%$. In eight voivodeships a reduction in the GVA/PE in relation to the national average and in eight increase in this indicator was recorded. In relative terms, the largest relative regress in relation to the average was recorded in the Śląskie (-36.8), Małopolskie (-34.5) and Podkarpackie Voivodeships (-30.6), while the largest increase in the Mazowieckie $(+42.6)$, Pomorskie (24.6) and Podlaskie Voivodeships (+39.9) (Fig. 1). 


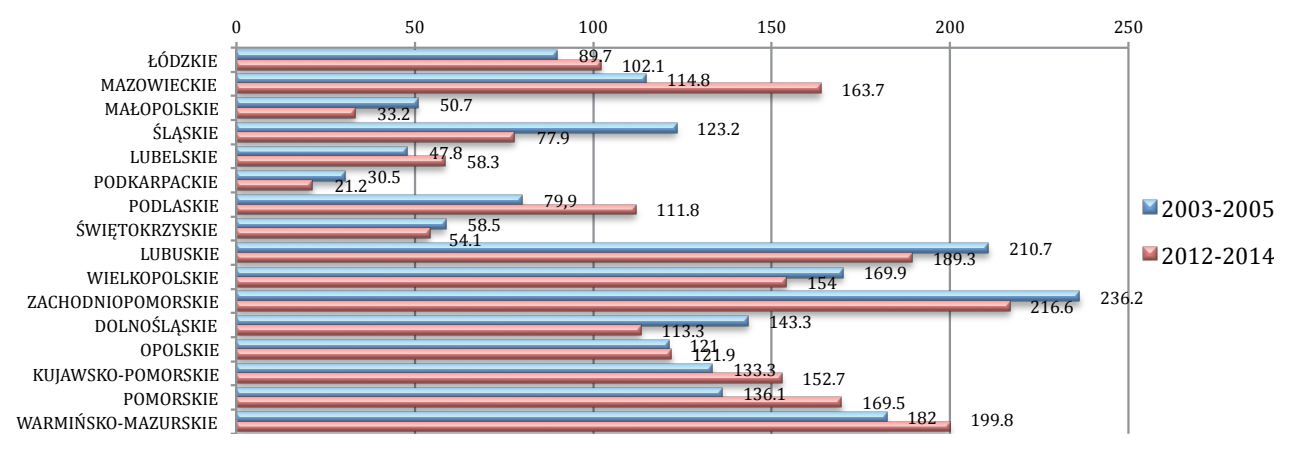

Fig. 1. Dynamics of distribution of the gross value added per one person working in relation to the country $(\%)$.

Source: as for Table 1.
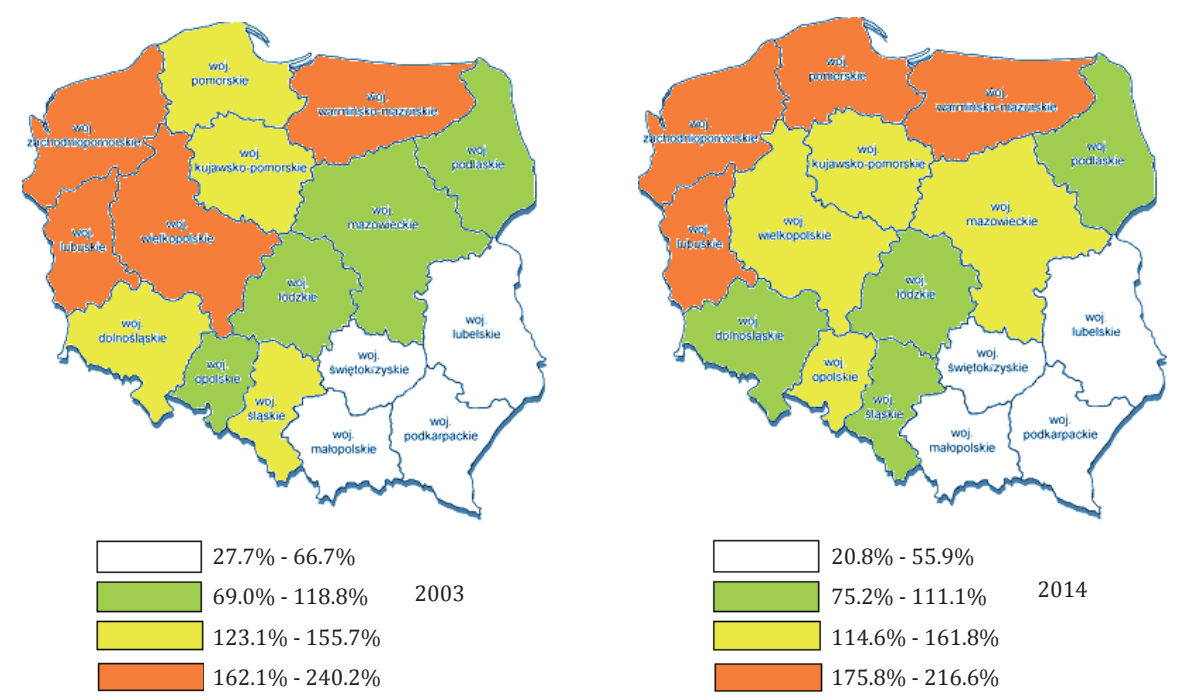

Fig. 2. Distribution of the relative gross value added per person employed in section A (agriculture, forestry, hunting and fishing) for voivodeships in 2003 and 2014.

Source: as for Table 1.

Distribution of the relative gross value added per person working in the initial and final period of the analysis divided into quartiles is presented on two consecutive maps (Fig. 2). In 2003, groups of voivodeships forming individual quartiles created complexes relatively easy to interpret. The first complex includes the area of south-eastern voivodeships of Poland, with traditional, fragmented agriculture, in which the GVA/PE was at a low level, from $28 \%$ to $67 \%$ of the national average. The second complex includes four voivodeships located diagonally from the south-west to the north-east of Poland. In this area, the level of the GVA/PE was close to the national average (69-119\%). The complex exceeding the average in- 
come between $123 \%$ and $156 \%$ consists of three separate groups of voivodeships: Pomorskie and Kujawsko-Pomorskie, Dolnośląskie and Śląskie. In this period, the highest productivity of labour was demonstrated by the Zachodniopomorkie, Lubuskie, Wielkopolskie and Warmińsko-Mazurskie Voivodeships. This complex includes voivodeships which had a large share of state-owned farms in the past.

Table 4

Distribution of the relative gross value added per person employed in section A

(agriculture, forestry, hunting and fishing)

for voivodeships (in \%) in the initial and final year of the analysis

\begin{tabular}{|c|c|c|c|c|c|c|}
\hline \multirow[b]{2}{*}{ Voivodeship } & \multicolumn{2}{|c|}{2003} & \multicolumn{2}{|c|}{2014} & \multicolumn{2}{|c|}{ Change } \\
\hline & GVA/PE & group & GVA/PE & group & $\begin{array}{l}\text { Percentage } \\
\text { points }\end{array}$ & group \\
\hline Dolnośląskie & 155.7 & 3 & 111.1 & 2 & -44.6 & 1 \\
\hline Kujawsko-Pomorskie & 123.1 & 3 & 153.5 & 3 & 30.4 & 4 \\
\hline Lubelskie & 52.2 & 1 & 55.9 & 1 & 3.6 & 3 \\
\hline Lubuskie & 181.9 & 4 & 196.3 & 4 & 14.4 & 3 \\
\hline Łódzkie & 88.7 & 2 & 109.5 & 2 & 20.8 & 3 \\
\hline Małopolskie & 50.9 & 1 & 33.6 & 1 & -17.3 & 1 \\
\hline Mazowieckie & 116.2 & 2 & 161.8 & 3 & 45.6 & 4 \\
\hline Opolskie & 118.8 & 2 & 114.6 & 3 & -4.2 & 2 \\
\hline Podkarpackie & 27.7 & 1 & 20.8 & 1 & -6.9 & 2 \\
\hline Podlaskie & 69.0 & 2 & 109.4 & 2 & 40.5 & 4 \\
\hline Pomorskie & 145.6 & 3 & 175.8 & 4 & 30.2 & 4 \\
\hline Śląskie & 133.1 & 3 & 75.2 & 2 & -57.9 & 1 \\
\hline Świętokrzyskie & 66.7 & 1 & 55.1 & 1 & -11.5 & 2 \\
\hline Warmińsko-Mazurskie & 191.1 & 4 & 199.2 & 4 & 8.1 & 3 \\
\hline Wielkopolskie & 162.1 & 4 & 154.0 & 3 & -8.1 & 2 \\
\hline Zachodniopomorskie & 240.2 & 4 & 216.6 & 4 & -23.5 & 1 \\
\hline Average & 120.2 & & 121.4 & & 1.2 & \\
\hline Standard deviation & 58.6 & & 61.4 & & 2.8 & \\
\hline Median & 121.0 & & 112.9 & & -8.1 & \\
\hline
\end{tabular}

Source: as for Table 1.

In 2014, relatively the smallest changes (slight decrease) occurred in the southeastern voivodeships. In 2003, three out of four voivodeships with the highest relative value of the GVA/PE maintained their position in the fourth group constituting $25 \%$ of voivodeships with the highest level of labour productivity. These were the following voivodeships: Zachodniopomorskie (216.6\%), Warmińsko-Mazurskie (199.2\%) and Lubuskie (196.3\%). The GVA/PE in the Wielkopolskie Voivodeship decreased by $-8.1 \mathrm{pp}$, and as a result this region moved to the third group, and its place was taken by the Pomorskie Voivodeship, which recorded an increase of 
+30 .2. Significant shifts occurred in two central quartiles. The Łódzkie and Podlaskie Voivodeships remained in the second group, the Opolskie and Mazowieckie Voivodeships advanced from the second to the third group, while the Śląskie and Dolnośląskie Voivodeships recorded the highest decrease in the relative GVA/PE, on average by $-51.3 \mathrm{pp}$, which caused them to fall from the third to the second category (Table 4).

Changes in the distribution which occurred in the level of the GVA/PE between 2003 and 2014 are shown in Table 4 and Figure 3. Relatively strong losses in productivity in the 17-58\% range occurred in the Małopolskie, Sląskie, Dolnośląskie and Zachodniopomorskie Voivodeships. These are regions with different characteristics of agriculture.

Between 2003 and 2014, there was an average positive change in the relative GVA/PE by $+1.2 \mathrm{pp}$. The highest increase was achieved in the Mazowieckie Voivodeship (+45.6 pp), Podlaskie Voivodeship (+40.5 pp), Kujawsko-Pomorskie Voivodeship (+30.4 pp) and Pomorskie Voivodeship (+30.2 pp). For half of the voivodeships, in 2003-2014, the analysed rate decreased. Relatively small movements, both down and up, took place in the following voivodeships: Opolskie, Podkarpackie and Wielkopolskie (slight decrease) and Lubelskie and WarmińskoMazurskie (slight increase). These changes are illustrated in Figure 3.

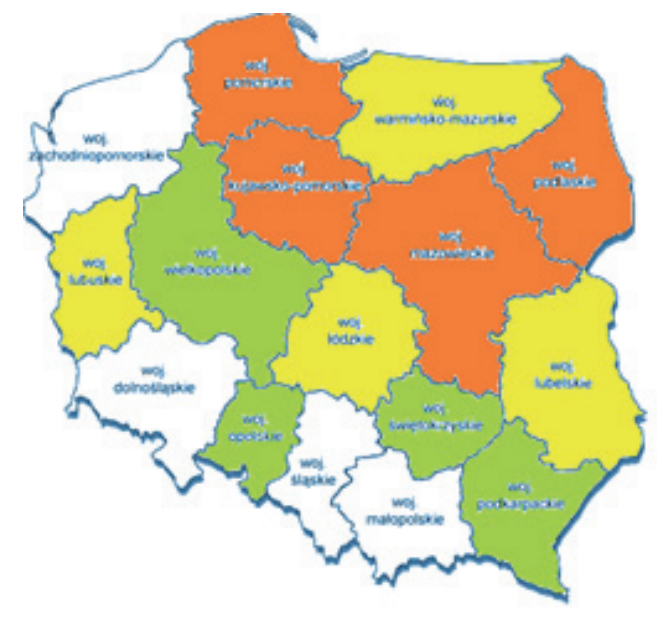

Change

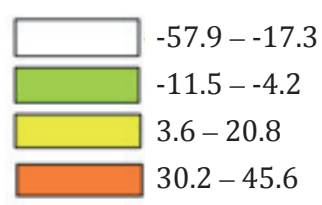

Fig. 3. Change in the distribution of the relative gross value added per person employed in section A (agriculture, forestry, hunting and fishing) for voivodeships in 2003-2014.

Source: as for Table 1.

Figure 4 shows the analysis of sigma-convergence/divergence for all regions using the course of changes of the coefficient of variation of the relative value added per person employed in section A in 2003-2014. Three phases can be distinguished from the course of the curve illustrating changes in the coefficient of variation in the analysed period: convergence, divergence and stagnation. In the analysed pe- 
riod between 2003 and 2014, initially the coefficient of variation decreased from $24.4 \%$ in 2003 to $17.9 \%$ in 2008, which coincides with the first stage of support for the Polish agriculture from the EU budget. This period can be treated as the time in which the convergence of voivodeships occurred. In the second stage (2008-2010), an increase in the coefficient of variation of the GVA/PE from $17.9 \%$ to $26.6 \%$ occurred. This proves the deepening of differences between regions, as a result of which within two years the differences between the examined voivodeships increased to a level exceeding the initial value from the period before Poland's accession to the EU. The third period under consideration, namely 2010-2014, except for 2011 when a positive change occurred, is characterised by stability at a high level of variability of $25-27 \%$. This period can be called a period of "stagnation" - or a time in which the differences between the regions did not increase, but also did not decrease (Fig. 4).

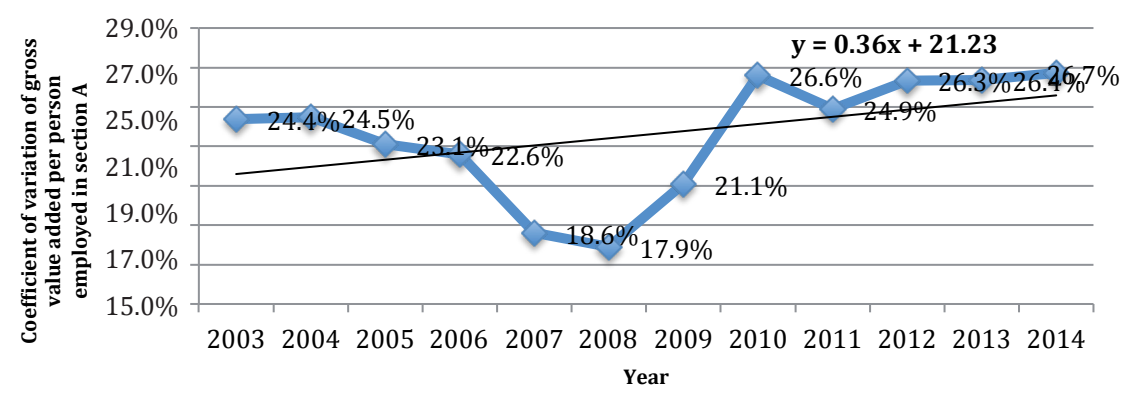

Fig. 4. Sigma-convergence analysis of the gross value added per person employed in section A (agriculture, forestry, hunting and fishing) for voivodeships.

Source: as for Table 1.

$\operatorname{Beta}(\beta)$ convergence will be evaluated further in this paper. Figure 5 presents the characteristics concerning the level of dependence between the average productivity growth rate in individual voivodeships (vertical axis) and their initial level (horizontal axis). It can be noticed that the poorest regions of fragmented agriculture (Podkarpackie, Małopolskie and Świętokrzyskie Voivodeships), but also industrialised regions (Śląskie and Dolnośląskie) recorded relatively low growth, not exceeding 4\%. On the other hand, Zachodniopomorskie, Wielkopolskie and Lubuskie Voivodeships recorded an average increase of 4-7\%. The Podlaskie and Mazowieckie Voivodeships showed the highest increase, while the Śląskie and Małopolskie Voivodeships the lowest. The above analysis does not indicate the occurrence of absolute beta-convergence of voivodeships in 2003-2014. Regions with lower labour productivity did not develop faster than the regions with medium and high level of the GVA/PE. 


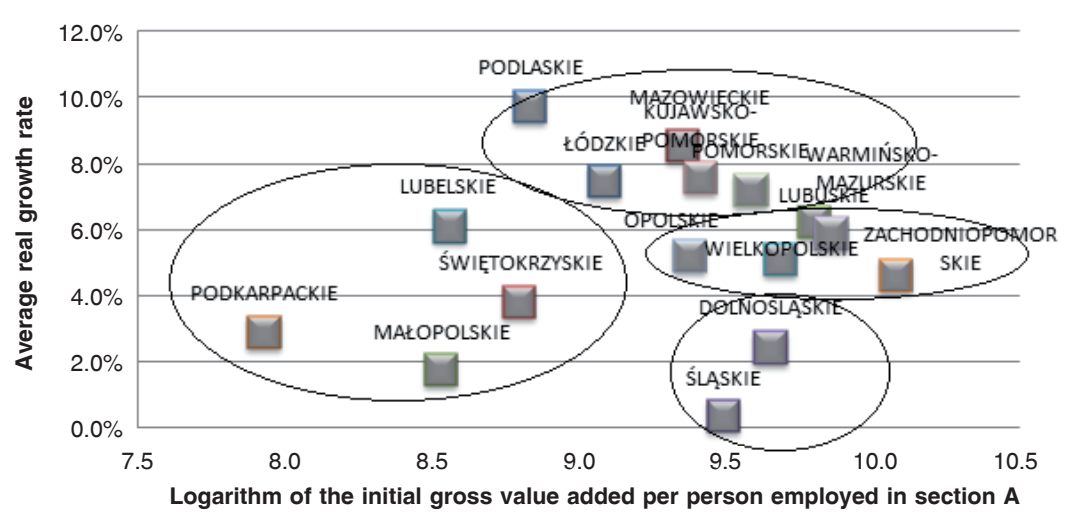

Fig. 5. Beta-convergence analysis of the gross value added per person employed in section A (agriculture, forestry, hunting and fishing) for voivodeships in 2003-2014.

Source: as for Table 1.

In order to eliminate short-term randomness and highlight the key change tendencies over time, the entire researched period was divided into four three-year sub-periods. For each period, the arithmetic mean of the relative gross value added per employee in section A was calculated, and then the limits of the ranges were determined creating four equipotent groups. Four south-eastern voivodeships of fragmented agriculture (Podkarpackie, Małopolskie, Lubelskie and Świętokrzyskie) in each of the four stages remained in the first group in which the average relative gross value added per employee in section A did not exceed $69.2 \%$ of the national average. After the first period, the Wielkopolskie Voivodeship shifted from the fourth to the third category and the Kujawsko-Pomorskie and Śląskie Voivodeships moved from the third to the second category. At the same time, the Mazowieckie Voivodeship shifted from the second to the third category. This period, despite the lack of a major increase in productivity of the poorest voivodeships under the influence of lower productivity of the richest ones (belonging to the $3^{\text {rd }}$ and $4^{\text {th }}$ group), proves the regional convergence.

The next analysed period (2009-2011) brought a decrease for the Dolnośląske Voivodeship from the third to the second category and an increase of the Kujawsko-Pomorskie and Opolskie Voivodeships from the second to the third category. In this period, the number of regions with the lowest and highest productivity did not change, while the number of the second group increased and the number of the third group decreased. In the last analysed period, the third group, the largest in 2009-2011, with a relatively high level of productivity was broken down. The Opolskie Voivodeship returned to the second category, while the Pomorskie and Mazowieckie Voivodeships advanced to the fourth - the highest category. As a result, a group of 5 voivodeships with the highest level of GVA/PE was formed, including the Zachodniopomorskie, Warmińsko-Mazurskie, Lubuskie, Pomorskie and Mazowieckie Voivodeships. Two voivodeships were at the medium high level of productivity: Kujawsko-Pomorskie and Wielkopolskie. The group with an aver- 
age GVA/PE included five voivodeships. The category with the lowest productivity is invariably represented by the voivodeships of south-eastern Poland. During three transitions between the distinguished periods, five falls to the lower category and five increases were observed. The Mazowieckie Voivodeship, which in 2003-2005 belonged to the second category, in 2006-2008 advanced to the third category, and in the last analysed period moved to the fourth group with a high level of productivity, strengthened the most. In 2006-2008 and 2009-2011, increases and decreases in productivity balanced. In this period, from 2006 to 2011, the second and third group close to the average included a total of nine voivodeships $(56.3 \%)$. With the stabilisation of a number of voivodeships in the first group with the lowest labour productivity, the number of voivodeships with the highest GVA/PE ratio was limited. This may support the occurrence of rather undesirable convergence of regions through a relative reduction in labour productivity in the group of the most productive regions. In the last period, from 2008 to 2014, layered convergence occurred. This means that the regions in the middle groups with the GVA/PE ratio above and below the national average moved up. This resulted in an increase in the number of regions with higher productivity. With the stabilisation of the group of regions with low labour productivity, the group with productivity above the national average included 7 voivodeships, while the group below the average 9 voivodeships. A decrease in the number of regions close to the average in the group of regions with above average GVA/PE and an increase in the number of voivodeships with a high level of productivity is an indication that the phenomenon of club convergence of regions occurred (Fig. 6).

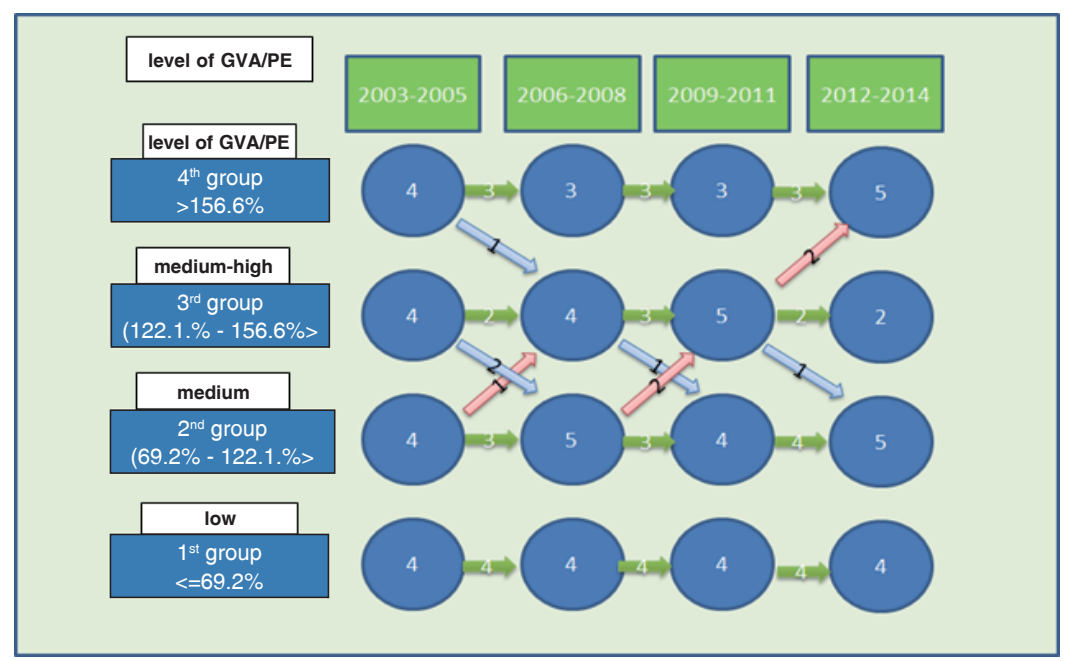

Fig. 6. The flow of regions according to the relative distribution of the gross value added per person employed in section A (agriculture, forestry, hunting and fishing) for voivodeships in four sub-periods in 2003-2014.

Source: as for Table 1. 
While analysing the flows of voivodeships between individual groups in the distinguished periods, it can be noticed that in 2003-2005 convergence as a result of lowering productivity in groups with high and medium-high productivity dominated. In 2006-2011, this earlier trend was offset by a larger flow from group 2 to group 3 . In 2009-2014, there is a predominance of flows from the medium-high group to high productivity over the flows of voivodeships from the medium-high group to the average level of productivity. In the entire period, a group of four voivodeships with the lowest productivity (group 1) was characterised by a clear stagnation.

Table 5

Flows of regions between four groups of agricultural productivity between the initial and final period of 2003-2014

\begin{tabular}{lccc}
\hline $\begin{array}{c}\text { Productivity level } \\
\text { in the voivodeship GVA/PE }\end{array}$ & $\begin{array}{c}\text { Number of regions } \\
\text { in 2003-2005 }\end{array}$ & $\begin{array}{c}\text { Number of regions } \\
\text { in 2012-2014 }\end{array}$ & $\begin{array}{c}\text { Balance of flows } \\
\text { +growth -loss }\end{array}$ \\
\hline high & 4 & 5 & +1 \\
medium-high & 4 & 2 & -2 \\
average & 4 & 5 & +1 \\
low & 4 & 4 & 0 \\
\hline
\end{tabular}

Source: as for Table 1 .

Based on the analysis of data included in Figure 6 and Table 5, it can be said that changes in the productivity of agriculture in the voivodeship in Poland in 20032014 are difficult to interpret unequivocally. It can be concluded that there is a clear stratification of voivodeships in terms of changes in productivity. Two groups of regions, the fourth group with high productivity and the second group with medium productivity, increased their number from four to five. The second group of regions with medium-high productivity decreased from four to two regions through outflow to both higher and lower productivity groups. Two groups of average productivity showed typical features of club convergence. The behaviour of voivodeships in the first group, with a low level of productivity, is similar. Changes which took place in this group were small and occurred within the group, which prevented them from moving to a higher level of productivity. Therefore, this group did not show the expected tendency to catch up with regions with higher productivity.

\section{Convergence and the use of the European funds}

One of the objectives of the study was to assess the connection of the phenomena of convergence with the level of use of financial resources from the EU funds targeting the objectives of rural development in individual voivodeships. The analysis of the interrelation between the use of European funds and the size of GVA, using the correlation calculus between these values, was used to assess this issue. However, a limited publication framework does not allow a broader analysis of factors influencing the phenomenon of labour productivity convergence in the regions. 
Table 6 presents the value of funds obtained from the EU budget by individual voivodeships in 2004-2014. A general upward trend in the use of the European funds (EF) can be observed, although this trend was characterised by variable intensity. On average, in Poland, there is a certain slump in steady growth in 2007, 2012 and 2014 (Table 6).

Table 6

Value of funds obtained for agriculture from the EF in 2004-2014 (PLN million)

\begin{tabular}{|c|c|c|c|c|c|c|c|c|c|c|c|}
\hline Voivodeship & 2004 & 2005 & 2006 & 2007 & 2008 & 2009 & 2010 & 2011 & 2012 & 2013 & 2014 \\
\hline Dolnośląskie & 181.1 & 547.2 & 714.2 & 719.3 & 924.0 & 1041.1 & 964.3 & 1308.9 & 1512.9 & 1545.2 & 1389.0 \\
\hline $\begin{array}{l}\text { Kujawsko- } \\
\text {-pomorskie }\end{array}$ & 286.3 & 728.6 & 1268.8 & 981.2 & 1400.7 & 1481.0 & 1569.1 & 1566.2 & 1945.7 & 1999.9 & 1868.0 \\
\hline Lubelskie & 340.2 & 876.2 & 1205.6 & 1372.2 & 1524.3 & 1780.5 & 1885.8 & 2201.1 & 2571.6 & 2653.3 & 2674.6 \\
\hline Lubuskie & 35.2 & 279.1 & 400.7 & 304.4 & 474.1 & 529.1 & 493.3 & 691.2 & 590.6 & 767.4 & 755.3 \\
\hline Łódzkie & 203.3 & 736.1 & 1037.7 & 1074.0 & 1276.1 & 975.2 & 1343.0 & 1581.8 & 1645.4 & 1997.2 & 1784.8 \\
\hline Małopolskie & 190.3 & 432.9 & 596.5 & 532.4 & 672.1 & 563.9 & 701.6 & 940.4 & 978.4 & 1107.8 & 1288.1 \\
\hline Mazowieckie & 348.3 & 1410.2 & 2355.8 & 1948.9 & 2366.1 & 2474.9 & 2884.4 & 3647.4 & 3489.5 & 4038.8 & 3948.7 \\
\hline Opolskie & 111.1 & 297.6 & 370.2 & 429.8 & 562.5 & 532.2 & 608.8 & 791.1 & 667.8 & 790.8 & 799.5 \\
\hline Podkarpackie & 171.5 & 407.0 & 530.8 & 563.1 & 579.2 & 558.1 & 723.5 & 967.8 & 1012.3 & 1112.0 & 1217.8 \\
\hline Podlaskie & 154.0 & 794.6 & 1520.1 & 860.6 & 1340.3 & 1317.4 & 1534.6 & 1959.5 & 1433.8 & 1746.3 & 1652.2 \\
\hline Pomorskie & 194.4 & 575.2 & 870.0 & 658.9 & 962.8 & 1002.4 & 1254.1 & 1349.4 & 1240.2 & 1614.3 & 1353.9 \\
\hline Śląskie & 116.8 & 343.8 & 310.4 & 344.0 & 350.7 & 390.6 & 444.9 & 656.4 & 746.5 & 764.7 & 735.2 \\
\hline Świętokrzyskie & 161.6 & 375.2 & 583.2 & 572.4 & 580.5 & 611.1 & 772.7 & 950.5 & 979.2 & 1174.5 & 1117.2 \\
\hline $\begin{array}{l}\text { Warmińsko- } \\
\text {-mazurskie }\end{array}$ & 139.9 & 666.3 & 1182.5 & 808.0 & 1055.4 & 1230.9 & 1183.4 & 1492.0 & 1399.2 & 1768.0 & 1347.0 \\
\hline Wielkopolskie & 288.1 & 1400.9 & 1965.1 & 1683.7 & 2224.8 & 2150.2 & 2336.2 & 3028.3 & 3160.8 & 3132.1 & 2828.2 \\
\hline $\begin{array}{l}\text { Zachodnio- } \\
\text { pomorskie }\end{array}$ & 82.1 & 627.0 & 757.8 & 676.0 & 975.6 & 1201.4 & 1012.3 & 1530.1 & 1186.0 & 1689.3 & 1357.4 \\
\hline Average & 187.8 & 656.1 & 979.3 & 845.6 & 1079.3 & 1115.0 & 1232.0 & 1541.4 & 1535.0 & 1743.9 & 1632.3 \\
\hline
\end{tabular}

Source: own study based on data from the ARMA.

Table 7 presents the dynamics of distribution of the level of gross value added per value of funding obtained from the EU. In 2004, the ratio of GVA to the amount of funding obtained from the European funds (area payments, RDP, SAPARD, SOP, Rural Development, Fisheries) ran from 5.34 in the Lubelskie Voivodeship to 24.66 in the Lubuskie Voivodeship, with the national average of 10.64. The year2004, was a transition year from pre-accession financing to the use of the EU funds available to the EU members. In subsequent years of financing, after obtaining the EU membership in 2004, the indicator was decreasing and in 2014 it reached the average value of 1.57 (Table 7). 
Table 7

Dynamics of distribution of the gross value added per funding obtained from the EF in regions $(P L N)$

\begin{tabular}{|c|c|c|c|c|c|c|c|c|c|c|c|}
\hline \multirow{2}{*}{ Voivodeship } & \multicolumn{11}{|c|}{ Year } \\
\hline & 2004 & 2005 & 2006 & 2007 & 2008 & 2009 & 2010 & 2011 & 2012 & 2013 & 2014 \\
\hline Dolnośląskie & 7.78 & 2.43 & 1.73 & 2.25 & 1.43 & 1.34 & 1.64 & 1.51 & 1.23 & 1.20 & 1.28 \\
\hline $\begin{array}{l}\text { Kujawsko- } \\
\text {-Pomorskie }\end{array}$ & 8.45 & 2.77 & 1.51 & 2.29 & 1.48 & 1.52 & 1.54 & 1.77 & 1.45 & 1.64 & 1.61 \\
\hline Lubelskie & 5.34 & 1.87 & 1.32 & 1.78 & 1.45 & 1.24 & 1.42 & 1.60 & 1.27 & 1.35 & 1.18 \\
\hline Lubuskie & 24.66 & 2.72 & 1.64 & 2.90 & 1.54 & 1.64 & 2.00 & 1.74 & 2.00 & 1.65 & 1.71 \\
\hline Łódzkie & 12.04 & 3.09 & 2.37 & 3.00 & 2.35 & 2.83 & 2.12 & 2.13 & 1.91 & 1.72 & 2.01 \\
\hline Małopolskie & 6.44 & 3.02 & 2.25 & 3.53 & 2.59 & 2.76 & 2.15 & 1.96 & 1.73 & 1.50 & 1.30 \\
\hline Mazowieckie & 14.26 & 3.54 & 2.30 & 3.40 & 2.83 & 2.59 & 2.55 & 2.44 & 2.46 & 2.46 & 2.26 \\
\hline Opolskie & 7.62 & 2.74 & 2.15 & 2.32 & 1.52 & 1.54 & 1.72 & 1.60 & 1.81 & 1.44 & 1.31 \\
\hline Podkarpackie & 3.76 & 1.78 & 1.31 & 1.93 & 1.71 & 1.61 & 1.17 & 1.11 & 0.96 & 0.98 & 0.81 \\
\hline Podlaskie & 10.22 & 2.07 & 1.10 & 2.26 & 1.35 & 1.60 & 1.44 & 1.30 & 1.70 & 1.66 & 1.53 \\
\hline Pomorskie & 5.91 & 1.75 & 1.17 & 2.09 & 1.22 & 1.35 & 1.30 & 1.39 & 1.58 & 1.27 & 1.55 \\
\hline Śląskie & 9.59 & 3.34 & 3.02 & 3.67 & 3.47 & 3.17 & 2.76 & 2.26 & 2.02 & 1.93 & 1.90 \\
\hline Świętokrzyskie & 7.24 & 2.58 & 1.75 & 2.39 & 2.17 & 2.04 & 1.65 & 1.67 & 1.46 & 1.33 & 1.35 \\
\hline $\begin{array}{l}\text { Warmińsko- } \\
\text {-Mazurskie }\end{array}$ & 11.58 & 2.38 & 1.34 & 2.16 & 1.46 & 1.48 & 1.85 & 1.76 & 1.81 & 1.47 & 1.87 \\
\hline Wielkopolskie & 17.81 & 3.40 & 2.28 & 2.88 & 1.85 & 2.18 & 2.17 & 1.85 & 1.88 & 2.00 & 2.13 \\
\hline $\begin{array}{l}\text { Zachodnio- } \\
\text { pomorskie }\end{array}$ & 17.47 & 2.00 & 1.75 & 2.07 & 1.28 & 1.25 & 1.61 & 1.14 & 1.54 & 1.19 & 1.41 \\
\hline Average & 10.64 & 2.59 & 1.81 & 2.56 & 1.86 & 1.88 & 1.82 & 1.70 & 1.68 & 1.55 & 1.57 \\
\hline
\end{tabular}

Source: own study based on data from the ARMA and the Local Data Bank.

In 2004, the relative gross value added per funding obtained from the European funds $(\mathrm{GVA} / \mathrm{EF})$ reached the highest value in the case of the Lubuskie Voivodeship (248.3\%), Wielkopolskie Voivodeship (179.2\%) and Zachodniopomorskie Voivodeship (175.8\%). The lowest value of the GVA/EF in 2004 was recorded by the Podkarpackie (37.9\%), Lubelskie $(53.8 \%)$ and Pomorskie Voivodeships $(59.5 \%)$. These differences result mainly from the diversified use of pre-accession funds of the SAPARD. After obtaining membership and covering the entire agriculture with financing from the European funds, these disproportions were significantly reduced. In 2014, the average value of the GVA/EF decreased from 107.1\% to $94.7 \%$, with the highest values for the Mazowieckie Voivodeship (136.1\%), Wielkopolskie Voivodeship (127.8\%) and Łódzkie Voivodeship (120.9\%). While in 2004 the extreme size of the indicators ranged from 37.9\% (Podkarpackie Voivodeship) to $248.3 \%$ (Lubuskie Voivodeship ), in 2014, the extreme values decreased to the value from 48.7\% (Podkarpackie Voivodeship) to 136.1\% (Mazowieckie Voivodeship) (Table 8). 
Table 8

Dynamics of distribution of the gross value added per EF obtained in regions in relation to the country (\%)

\begin{tabular}{|c|c|c|c|c|c|c|c|c|c|c|c|}
\hline \multirow{2}{*}{ Voivodeship } & \multicolumn{11}{|c|}{ Year } \\
\hline & 2004 & 2005 & 2006 & 2007 & 2008 & 2009 & 2010 & 2011 & 2012 & 2013 & 2014 \\
\hline Dolnośląskie & 78.4 & 90.4 & 96.3 & 87.2 & 77.2 & 71.9 & 88.7 & 85.7 & 71.1 & 72.5 & 77.0 \\
\hline $\begin{array}{l}\text { Kujawsko- } \\
\text {-Pomorskie }\end{array}$ & 85.1 & 103.0 & 84.3 & 88.7 & 79.7 & 81.9 & 83.1 & 100.4 & 84.0 & 99.0 & 96.8 \\
\hline Lubelskie & 53.8 & 69.5 & 73.7 & 68.9 & 78.3 & 66.7 & 76.6 & 91.0 & 73.7 & 81.6 & 70.8 \\
\hline Lubuskie & 248.3 & 101.0 & 91.1 & 112.4 & 83.4 & 88.6 & 108.0 & 99.0 & 115.8 & 100.2 & 103.1 \\
\hline Łódzkie & 121.2 & 114.9 & 131.9 & 116.2 & 126.7 & 152.7 & 114.5 & 121.2 & 110.9 & 104.2 & 120.9 \\
\hline Małopolskie & 64.8 & 112.3 & 125.1 & 136.6 & 139.8 & 148.4 & 116.2 & 111.4 & 100.6 & 90.6 & 78.2 \\
\hline Mazowieckie & 143.5 & 131.6 & 128.3 & 131.5 & 153.0 & 139.3 & 137.6 & 138.6 & 142.5 & 149.0 & 136.1 \\
\hline Opolskie & 76.7 & 101.8 & 119.5 & 89.8 & 82.1 & 82.9 & 92.8 & 90.8 & 104.8 & 87.1 & 78.9 \\
\hline Podkarpackie & 37.9 & 66.2 & 73.0 & 74.7 & 92.6 & 86.7 & 63.2 & 63.2 & 55.9 & 59.2 & 48.7 \\
\hline Podlaskie & 102.9 & 77.2 & 61.3 & 87.6 & 72.9 & 86.4 & 77.8 & 73.7 & 98.6 & 100.4 & 92.1 \\
\hline Pomorskie & 59.5 & 65.3 & 64.9 & 80.8 & 65.6 & 72.5 & 70.1 & 78.7 & 91.7 & 76.9 & 93.0 \\
\hline Śląskie & 96.6 & 124.2 & 168.1 & 142.0 & 187.5 & 170.6 & 149.2 & 128.6 & 117.1 & 117.0 & 114.1 \\
\hline Świętokrzyskie & 72.9 & 96.0 & 97.2 & 92.6 & 117.4 & 110.1 & 89.1 & 95.1 & 84.8 & 80.5 & 81.1 \\
\hline $\begin{array}{l}\text { Warmińsko- } \\
\text {-Mazurskie }\end{array}$ & 116.6 & 88.4 & 74.4 & 83.4 & 78.7 & 79.5 & 100.1 & 100.1 & 105.2 & 88.8 & 112.5 \\
\hline Wielkopolskie & 179.2 & 126.4 & 126.7 & 111.6 & 99.9 & 117.6 & 117.3 & 105.2 & 108.8 & 121.1 & 127.8 \\
\hline $\begin{array}{l}\text { Zachodnio- } \\
\text { pomorskie }\end{array}$ & 175.8 & 74.3 & 97.3 & 80.1 & 69.2 & 67.5 & 87.0 & 64.9 & 89.5 & 72.1 & 84.5 \\
\hline Average & 107.1 & 96.4 & 100.8 & 99.0 & 100.2 & 101.5 & 98.2 & 96.7 & 97.2 & 93.8 & 94.7 \\
\hline
\end{tabular}

Source: as for Table 7.

While analysing the three-year periods, the largest positive change in the GVA/ EF rate was recorded by the following voivodeships: Pomorskie (+37.9 pp), Wielkopolskie (+30.3 pp) and Podlaskie (+20.6 pp). A negative change affected half of the voivodeships, including Lubuskie Voivodeship (-27.5 pp), Dolnośląskie Voivodeship (-16.8 pp) and Małopolskie Voivodeship (-10.9 pp) (Table 9 and Fig. 7). 
Table 9

Dynamics of distribution of the gross value added per EF obtained in regions in relation to the country ${ }^{a}$

\begin{tabular}{lcccc}
\hline \multicolumn{1}{c}{ Voivodeship } & $2004-2006$ & $2012-2014$ & $\begin{array}{c}\text { Change } \\
\text { (percentage points) }\end{array}$ & Change (\%) \\
\hline Dolnośląskie & 88.4 & 73.5 & -14.8 & -16.8 \\
Kujawsko-Pomorskie & 90.8 & 93.3 & 2.5 & 2.7 \\
Lubelskie & 65.7 & 75.4 & 9.7 & 14.8 \\
Lubuskie & 146.8 & 106.4 & -40.4 & -27.5 \\
Łódzkie & 122.7 & 112.0 & -10.7 & -8.7 \\
Małopolskie & 100.7 & 89.8 & -10.9 & -10.9 \\
Mazowieckie & 134.5 & 142.5 & 8.1 & 6.0 \\
Opolskie & 99.3 & 90.3 & -9.1 & -9.1 \\
Podkarpackie & 59.0 & 54.6 & -4.4 & -7.5 \\
Podlaskie & 80.5 & 97.0 & 16.6 & 20.6 \\
Pomorskie & 63.2 & 87.2 & 24.0 & 37.9 \\
Śląskie & 129.6 & 116.1 & -13.6 & -10.5 \\
Świętokrzyskie & 121.6 & 121.9 & 0.3 & 0.2 \\
Warmińsko-Mazurskie & 133.5 & 152.7 & 19.1 & 14.3 \\
Wielkopolskie & 130.1 & 169.5 & 39.4 & 30.3 \\
Zachodniopomorskie & 178.7 & 199.8 & 21.1 & 11.8 \\
Average & 109.1 & 111.4 & 2.3 & 2.1 \\
Standard deviation & 33.6 & 38.3 & 4.7 & -9.5 \\
Median & 111.2 & 101.7 & -5.5 \\
\hline
\end{tabular}

${ }^{a}$ Three-year averages from the initial and final period of analysis in \% in 2004-2006 and in 2012-2014.

Source: as for Table 7.

The median of change was: $-9.5 \mathrm{pp}$, which indicates that half of the studied voivodeships recorded a loss in the analysed indicator by $-9.5 \mathrm{pp}$, from $111.2 \%$ to $101.7 \%$. Eight voivodeships noted a reduction in the GVA/PE in relation to the national average and eight an increase in this indicator (Fig. 7). 


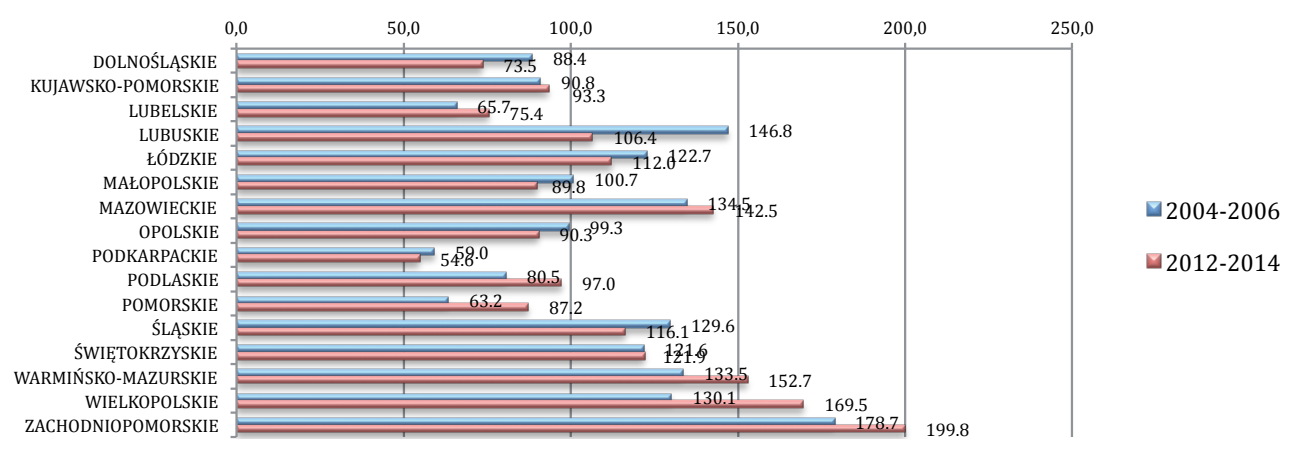

${ }^{a}$ Three-year averages from the initial and final period of analysis in \% in 2004-2006 and in 2012-2014.

Fig. 7. Changes in distribution of the gross value added per EF obtained in relation to the countrya. Source: as for Table 7.

The value of the coefficient of variation of the relative GVA/EF in 2004 was $42.1 \%$ and by 2014 it decreased to $22.3 \%$. The course of the coefficient of variation of the GVA/PE in 2004-2014 indicates the occurrence of convergence of regions. The slope of the regression line of the relative size of GVA/EF assumed a negative value (-1.11), which confirms the convergence of the regions (Fig. 8).

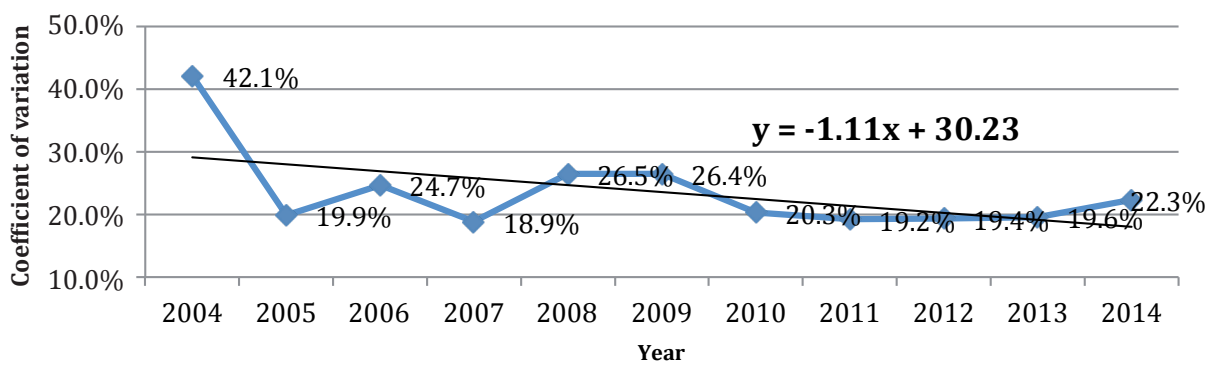

Fig. 8. Analysis of sigma-convergence of the gross value added per funding obtained from EF 2004-2014.

Source: as for Table 7.

In the case of analysis of the beta-convergence rate, there was a large increase in the rate of voivodeships where the GVA/EF logarithm was relatively low, and very low increase in voivodeships whose initial GVA/EF value was high. The above situation confirms the occurrence of convergence of the regions (Fig. 9). 


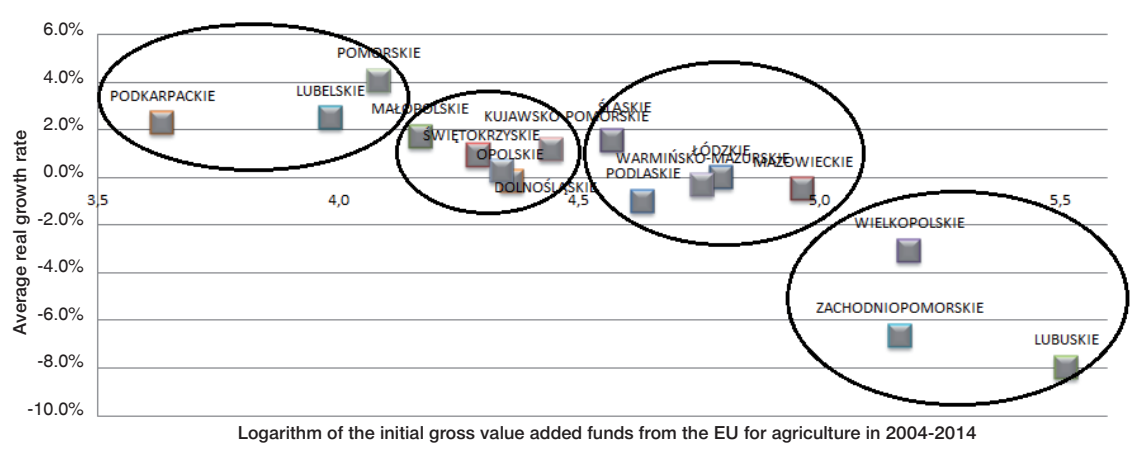

Fig. 9. Analysis of beta-convergence of the gross value added per European Union funds obtained by the voivodeships in Poland in 2004-2014.

Source: as for Table 7.

The highest correlation coefficient between the GVA and co-financing from EU funds in 2004-2014 was recorded in the case of the Mazowieckie Voivodeship ( $\mathrm{r}=0.92)$, Lubelskie Voivodeship $(\mathrm{r}=0.89)$ and Śląskie Voivodeship $(\mathrm{r}=0.86)$. The lowest was noted in the case of the Wielkopolskie Voivodeship $(r=0.56)$, Małopolskie Voivodeship ( $\mathrm{r}=0.59$ ) and Kujawsko-Pomorskie Voivodeship ( $\mathrm{r}=0.63)$. Nevertheless, in each case the correlation coefficient was positive and relatively high. While examining the relation between the GVA for whole Poland and the sum of funds obtained for agriculture in 2004-2014, a high positive correlation (0.87) was demonstrated (Fig. 10).

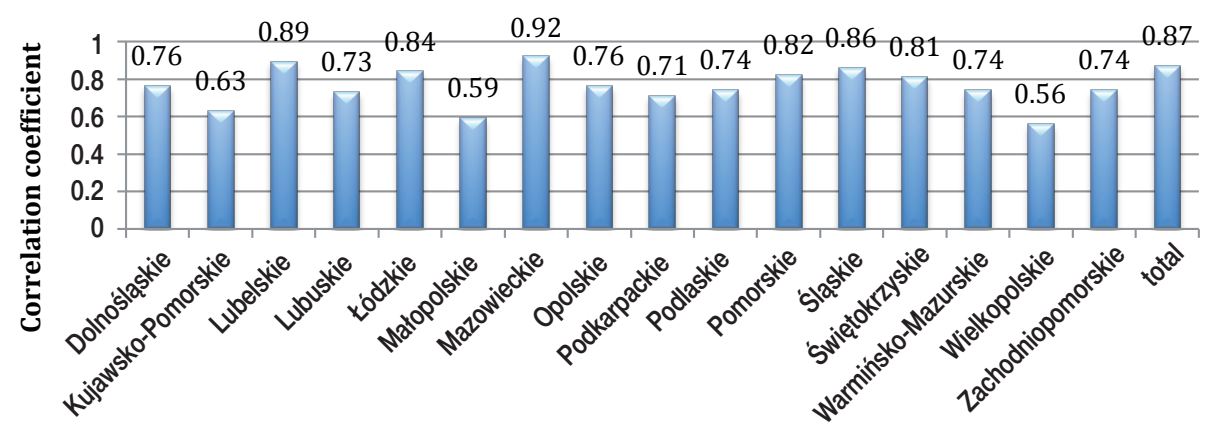

Fig. 10. The correlation coefficient of the gross value added and the EU funds obtained by all sectors in regions of Poland in 2004-2014.

Source: as for Table 7.

The high correlation coefficient of the GVA and funds obtained from the European Union was noticed only in the Mazowieckie and Lubelskie Voivodeships, and low in the Wielkopolskie, Małopolskie and Kujawsko-Pomorskie Voivodeships. This means that in the latter voivodeships, apart from funding from the EU, other factors played an important role. 


\section{Summary}

The reduction in disparities in development between countries and regions is one of the most important general objectives of the European integration. The funds of the Community budget directed to individual countries and regions through various European funds and policies serve this purpose. The task of these policies and funds is to support development of countries and regions lagging behind, which may result in the phenomenon of convergence. One of the most supported sectors of the economy is agriculture and other forms of farming in rural areas. In Poland, rural sectors of all regions benefited from the support of the Common Agricultural Policy and cohesion policy. Both the scope of the EU support for agriculture, forestry, hunting and fishing, and the effects of this support in Polish regions are different across Poland.

Both the phenomenon of sigma-convergence, indicating a reduction in disproportions and differences in the level of development, and the phenomenon of beta-convergence, indicating a faster rate of development of rural sectors in less developed regions (catching-up phenomenon), were subjected to studies. Studies showed that in 2003-2008, the coefficient of variation in the level of development of rural sectors decreased. This means the occurrence of the phenomenon of sigma-convergence in this period, as a result of faster development of less developed regions. On the other hand, in 2008-2010, the coefficient of variation increased, to stabilise at the high level of $25-27 \%$ in 2010-2014. This means that in the final years of the analysed period, the differences between regions did not deepen. The analysis of beta-convergence showed that the poorest regions, especially the regions of fragmented agriculture, recorded a relatively low increase in productivity (up to 4\%), while the Zachodniopomorskie, Pomorskie, Wielkopolskie and Lubuskie Voivodeships, with favourable agrarian structure, achieved an increase of 4-7\%. The lowest growth rates were reached by the Śląskie and Dolnośląskie Voivodeships, while the highest by the Mazowieckie, Podlaskie, Pomorskie and Kujawsko-Pomorskie Voivodeships. Considering these research results, it is hard to see the existence of permanent regional convergence of agricultural development and other rural sectors measured by the level of labour productivity. Periods of occurrence of the convergence are interwoven with the phenomenon of divergence or lack of changes.

One of the reasons for the lack of permanent, clearly visible phenomenon of convergence with a constant inflow of EU funds may be significant differences in labour productivity in agriculture resulting from structural differences in agriculture and other rural sectors in the Polish regions. The analysis of flows of individual regions between productivity groups confirmed the occurrence of different processes within four groups of voivodeships. Research showed stabilisation of labour productivity in the group of south-eastern voivodeships and stratification consisting in limiting the group of voivodeships representing medium-high level of productivity in favour of groups of voivodeships with high and medium productivity. Strengthening of two groups of voivodeships with high and medium level of productivity and stabilisation of the group with low productivity indicates the occurrence of the so-called club convergence. 
Although research showed only a partial occurrence of the phenomenon of regional convergence, expressed by the limitation of the volatility of gross value added per person employed in rural sectors, a direct comparison of this value with the amounts of funding obtained from the European Union in 2004-2014 turned out to be strongly correlated. Positive correlation of gross value added with funding obtained from the EU was recorded in all voivodeships. The analysis of gross value added rates per funding obtained from the EU shows a clear occurrence of both sigma-convergence and beta-convergence. This confirms the thesis about the positive impact of the EU funds on the level of production of agriculture, forestry, hunting and fishing in Poland. 


\section{References}

Baráth, L., Fertö, L. (2017). Productivity and convergence in Eurapan agriculture. Journal Agricultural Economics, vol. 68, no. 1, pp. 228-248.

Barro, R.J., Sala-i-Martin, X. (1992). Convergence. Journal of Political Economy, vol. 100, s. 223-251.

Brelik, A., Grzelak, A. (2011). Ocena tendencji w kształtowaniu się dochodów gospodarstw rolnych w Polsce w regionach FADN po integracji z UE. Journal of Agribusiness and Rural Development, no. 2(20), pp. 5-11.

Churski, P. (2005). Czynniki rozwoju regionalnego w świetle koncepcji teoretycznych. Zeszyty Naukowe WSHE we Włocławku, Nauki Ekonomiczne, vol. XIX, pp. 13-31.

Czyżewski, A., Kułyk, P. (2009). Konwergencja czy dywergencja mechanizmów wsparcia sektora rolnego. Zeszyty Naukowe SGGW, Problemy Rolnictwa Światowego, issue 8(23), pp. 41-51.

Fiedor, B., Kociszewski, K. (2010). Ekonomia rozwoju. Wrocław: Wydawnictwo Uniwersytetu Ekonomicznego.

Głodowska, A. (2012). Znaczenie konwergencji w aktualnej i przyszłej polityce strukturalnej Unii Europejskiej. Nierówności Społeczne a Wzrost Gospodarczy, no. 24, pp. 174-185.

Hamulczuk, M. (2015). Total factor productivity convergence in the EU agriculture. Proceedings of the Fourth International Conference Competitiveness of Agro-Food and Environmental Economy, pp. 34-43.

Kaczmarek, J. (2006). Zróżnicowanie regionalne potencjału produkcyjnego oraz wyników produkcyjno-ekonomicznych indywidualnych gospodarstw rolnych w Polsce z uwzględnieniem wybranych typów rolniczych. Problemy Rolnictwa Światowego, vol. 15, pp. 26-35.

Kamińska, A., Nowak, A. (2014). Zastosowanie analizy skupień do badania zróżnicowania regionalnego potencjału produkcyjnego rolnictwa w Polsce. Roczniki Naukowe SERiA, t. XVI, issue 3, pp. 26-35.

Łaźniewska, E., Górecki, T, Chmielewski, R. (2011). Konwergencja regionalna. Poznań: Wyd. Uniwersytetu Ekonomicznego w Poznaniu.

Majchrzak, A., Smędzik-Ambroży, K. (2014). Procesy konwergencji dochodów gospodarstw rolnych w Polsce po 2006 roku. Journal of Agribusiness and Rural Development, no. 1(31), pp. 89-98.

Malaga, K. (2004). Konwergencja gospodarcza w krajach OECD w świetle zagregowanych modeli wzrostu. Prace habilitacyjne, AkademiaEkonomiczna w Poznaniu (10).

Markowska-Przybyła,U.(2010). Konwergencja regionalna w Polsce w latach 1999-2007. Gospodarka Narodowa, no. 11-12, pp. 85-110.

Niewiadomski, K. (2009). Ocena konwergencji rolnictwa w Polsce w latach 1998-2005. Wieś i Rolnictwo, no. 3(144), pp. 49-62.

Nowak, A., Kamińska, A., Różańska-Boczula, M. (2014). Przestrzenne zróżnicowanie potencjału produkcyjnego rolnictwa w Polsce. Prace Naukowe Uniwersytetu Ekonomicznego we Wrocławiu, Ekonomia, no. 347, pp. 363-372.

Nowak, A. (2017). Przestrzenne zróżnicowanie zmian produktywności całkowitej rolnictwa w Polsce w latach 2005. Roczniki Naukowe SERiA, vol. XIX, issue 1, pp. 131-136.

Próchniak, M., Rapacki, P., (2007). Konwergencja beta i sigma w krajach postsocjalistycznych w latach 1990-2005. Beta and sigma Convergence in the Post-Socialist Countries. Bank i Kredyt, no. 8-9, pp. 42-60.

Rezitis, A.N. (2010). Agricultural Productivity and convergence. Europe and the United States Applied Economics, no. 42(8), pp. 1029-1044. 
Sala-i-Martin, X. (1996). The classical approach to convergence analysis. Economic Journal, vol. 106, pp. 1019-1036.

Sapa, A., Baer-Nawrocka, A. (2014). Konwergencja wydajności pracy w rolnictwie a intensywność handlu rolno-żywnościowego w amerykańskich ugrupowaniach handlowych. Gospodarka Narodowa, no. 3, pp. 111-131.

Skórka, A. (2013). Konwergencja czy dywergencja struktur zatrudnienia w Polsce i w UE-15? Studia Ekonomiczne, no. 160, pp. 64-72.

Smędzik-Ambroży, K. (2014). Konwergencja czy dywergencja rolnictwa $w$ Polsce $w$ latach 2004-2011. IX Kongres Ekonomistów Polskich.

Wójcik, P. (2008). Dywergencja czy konwergencja: dynamika rozwoju polskich regionów Studia Regionalne i Lokalne, no. 2(32), pp. 41-60. 


\title{
REGIONALNA KONWERGENCJA PRODUKTYWNOŚCI PRACY SEKTORÓW WIEJSKICH W KONTEKŚCIE ŚRODKÓW POZYSKANYCH NA ROLNICTWO Z UNII EUROPEJSKIEJ
}

\begin{abstract}
Abstrakt
Jednym z głównych celów integracji europejskiej jest redukcja dysproporcji rozwojowych określana mianem konwergencji. Konwergencja wystepuje $w$ dwóch formach jako konwergencja sigma $i$ konwergencja beta. Konwergencja sigma oznacza zmniejszenie z biegiem czasu dyspersji i zróżnicowania, istotą konwergencji beta jest szybszy rozwój regionów czy krajów słabiej rozwiniętych, co skutkuje efektem doganiania. Celem artykułu jest badanie konwergencji poziomu rozwoju sektorów gospodarki wiejskiej w regionach Polski w latach 2003-2014. Wyniki ekonomiczne, w kontekście rozmiaru pozyskanych środków z funduszy europejskich, mierzone wartościa dodana brutto: rolnictwa, leśnictwa, łowiectwa i rybactwa, pozyskano z Banku Danych Lokalnych. Dane o wartości wykorzystanych środków uzyskano z Agencji Restrukturyzacji i Modernizacji Rolnictwa. Do analizy wykorzystano metody statystyczne opisujace stan zróżnicowania regionów oraz funkcje regresji. Badania potwierdzity cześsciowe wystapienie zjawiska konwergencji produktywności pracy w sektorach wiejskich polskich regionów i dodatnia korelację wartości dodanej brutto z wysokościa pozyskanych środków z funduszy europejskich.
\end{abstract}

Słowa kluczowe: konwergencja, regiony, rozwój obszarów wiejskich.

Accepted for print: 5.09.2018.

Unless stated otherwise all the materials on the website are available under the Creative Commons Attribution 4.0 International license.

Some rights reserved to the Institute of Agricultural and Food Economics - National Research Institute.

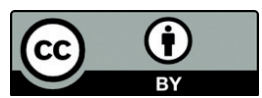

